\title{
INFLUENCE OF SALICYLIC ACID AND POTASSIUM NITRATE ON PLANT HEIGHT AND FLOWERING TIME OF GROUNDNUT (ARACHIS HYPOGAEA L.) UNDER VARYING SALINITY AND DROUGHT- INDUCED STRESSES
}

\author{
P. Nkrumah, A. M. Amadu And K. O. AyeH* \\ (Department of Plant and Environmental Biology, School of Biological Sciences, College \\ of Basic and Applied Sciences, University of Ghana, Legon, Ghana). \\ *Corresponding author's email: koayeh@ug.edu.gh
}

\begin{abstract}
This study was conducted to examine the effects of Salicylic acid (SA) and Potassium nitrate $\left(\mathrm{KNO}_{3}\right)$ on plant height and flowering time of groundnut (Arachis hypogaea L.) under induced stresses of salinity, drought and combined salinity and drought. Three watering regimes namely; normal, moderate and severe were used. For salinity stress, $50 \mathrm{mM} \mathrm{NaCl}, 100 \mathrm{mM} \mathrm{NaCl}, 150$ $\mathrm{mM} \mathrm{NaCl}$ and combination of water and salinity regimes were used. $50 \mu \mathrm{m} \mathrm{KNO}_{3}$ and $50 \mu \mathrm{m} \mathrm{SA}$ were separately applied to plants under water, salinity and combined water and salinity stresses. The mean plant height at $100 \mathrm{mM}$ salt concentration were $42.29 \mathrm{~cm}$ for $\mathrm{KNO}_{3}, 42.27 \mathrm{~cm}$ for $\mathrm{SA}$, compared with $40.98 \mathrm{~cm}$ for control $(\mathrm{F}=2.73 ; \mathrm{P} \leq 0.008)$. In combined severe watering and $150 \mathrm{mM} \mathrm{NaCl}$ treatment, flowering time was $57 \mathrm{DAP}$ (days after planting) compared to 34 DAP in control plants. When $\mathrm{KNO}_{3}$ and SA were applied to severe watering and $150 \mathrm{mM} \mathrm{NaCl}$ combined stress induced plants, flowering time was 51 DAP and 53 DAP for $\mathrm{KNO}_{3}$ and SA treated plants respectively. In conclusion, the exogenous application of plant growth regulators such as $\mathrm{SA}$ and $\mathrm{KNO}_{3}$ reduce impact of water stress on groundnut and effectively improve yield.
\end{abstract}

Keywords: Water and salinity stress, Arachis hypogaea L., salicylic acid, potassium nitrate, plant height and flowering

\section{Introduction}

Arachis hypogaea L. (groundnut) is one of the world's most popular crops cultivated throughout the tropical and sub-tropical areas where annual precipitation is between 1000 - $1200 \mathrm{~mm}$ for optimum growth of the crop (Shiyam, 2010). Groundnuts have a high nutrient content comprising $44-56 \%$ oil, 22 - 30\% protein, 9.5 - 19.0\% carbohydrates and a rich source of minerals (Jung et al., 2003) including calcium, magnesium, phosphorus, and potassium and vitamins $\mathrm{E}, \mathrm{K}$, and $\mathrm{B}$ (Gupta, 2012). Nonetheless, the cultivation of groundnuts may be negatively impacted by abiotic stress factors such as drought and salinity stresses not excepting plant disease.

Drought stress has become the main environmental factor leading to reduced agricultural productivity and food safety worldwide and has, therefore, become a major concern in crop production (Bodner et al., 2015; Fahad et al., 2017). Plants tolerate water deficit stress by morpho-physiological, biochemical, and anatomical adaptive mechanisms that involve osmotic change and stomatal closure, thereby enabling plants to 
withstand water stress (Basu et al., 2016). Salinity is a significant stress impacting worldwide crop productivity (Pitman \& Läuchli, 2002). More than $20 \%$ of the world's cultivated land is affected by salt stress and the average volume of salt increases (Gupta \& Huang, 2014). Salinity stress responses involve changes in different physiological and metabolic processes influenced by the intensity and length of the stress and eventually inhibits crop production (Pradheeban et al., 2017). During the initial phases of salinity stress, the water absorption potential of the root systems decreases, and water deficiency in leaves is increased by high salt and accumulation of other osmolytes in the soil (Hanumantharao et al., 2016; Gupta \& Huang, 2014);

Growth in height is necessary in most plants as it helps plants access light needed for its general growth and survival (Nagashima \& Hikosaka, 2011; Falster \& Westoby, 2003). Plant height usually increase as temperatures drop and soil conditions become moistier (Olson et al., 2018). This is evident in the vegetation zones in Ghana where herbs and shrubs are prominent in the savanna or desert areas and taller trees being prominent in the deciduous forest and rain forest zones (Asravor et al., 2019). When factors necessary to provide a plant with water needed to maintain turgor in its aerial tissues are limited, it results in water deficit or stress and plant height may be impacted (Niklas, 2007). Thus, diseases and other unfavourable ecophysiological conditions such as drought and salinity result in plant height reduction (Baher et al., 2002; Saadatmand et al., 2007).

Flowering is an important phase in the life cycle of angiosperms because it ensures seed dispersal through agents of pollination such as wind, insects, birds and bees. The process of flowering is dependent on prevailing environmental conditions and internal genetic factors so that there is transition from vegetative to reproductive growth and optimum conditions are met for fertilization and seed formation (Kazan \& Lyons, 2016; Liang et al., 2019). Drought causes early arrest of floral development and leads to sterility ( $\mathrm{Su}$ et al., 2013). Recent findings have shown that combined drought and heat stress during evocation may reduce silk and ovary growth, extend anthesis-silking interval in kernel number per plant in maize (Liu et al., 2020). Furthermore, there have been reports of the close association between flowering time and drought conditions in Sarcopoterium spinosum (Waitz et al., 2021). Studies have revealed that salt induced stress reduced flowering and fruit ripening, reduced fruit size and number per plant (Koffi et al., 2019). Recent research has indicated that plants ability to tolerate salinity stress do not only depend on species specificity but also on the degree of salinity tolerance experienced by the plant (Zunzunegui et al., 2021).

Plants have adapted to a broad array of mechanisms during their evolution to withstand a range of stressful conditions (Lamalakshmi Devi et al., 2017). These include the synthesis of potassium containing chemicals such as $\mathrm{KNO}_{3}$ and plant growth regulators such as SA. There is significant evidence that mineral nutrients play a critical role in a plant's resistance to stress. Out of all the mineral nutrients, potassium $(\mathrm{K})$ plays a critical role in plant growth and metabolism, and it contributes greatly to the survival of plants that are under various abiotic stresses. Potassium is an important mineral element in plants and is therefore considered the most abundant in most soils. It has been consistently found that the concentration of $\mathrm{K}^{+}$in the cytoplasm is between 100 and $200 \mathrm{mM}$ and that the concentration of apoplastic $\mathrm{K}^{+}$may vary between 10 and 200 or even reach up to $500 \mathrm{mM}$ (Wang et al., 2013). 
Salicylic acid (SA; 2-hydroxybenzoic acid) is one of several plant-synthesized phenolic compounds containing a benzene ring that carries one or more hydroxyl groups (Klessig \& Malamy, 1994). SA is an essential plant hormone that regulates plant growth and development (Dempsey \& Klessig, 2017). SA has been shown to enhance plant tolerance to major abiotic stresses such as salinity, drought, toxic metals and heat (Hasanuzzaman et al., 2017; Khan et al. 2015). It has been documented that exogenous application of SA to stressed plants either by seed soaking, addition to nutrient solution, irrigation or spraying induced significant biotic stress tolerance in plants (El-Katony et al., 2019; Khan et al., 2015). Information on combined abiotic stresses on plants such as groundnuts and some ameliorating effects to counteract some of the negative morphological and physiological responses of plants are scanty. The objective of this study, therefore, was to investigate the effects of varying water deficits, salinity and their combination on growth of economically important crop such as groundnut plant and integrate stress responses with flowering time and plant height. The influence of the mitigating effects of SA and $\mathrm{KNO}_{3}$ on plant height and flowering time of groundnut under water and salinity stresses were also investigated.

\section{Experimental}

\section{Plant material}

The study was conducted using a commercially grown groundnut variety in Ghana, Kumawu Red.

\section{Soil}

The soil type used in this study was Haatso Nyibgenya Series, obtained from the teaching garden in the Department of Plant and Environmental Biology, University of Ghana and sterilized at a temperature of $121^{\circ} \mathrm{C}$ and a pressure of $15 \mathrm{psi}$ for 20 mins. $30 \mathrm{~g}$ of soil was weighed and placed into polythene bags of dimension $20 \times 30 \mathrm{~cm}$. A total of 105 bags were used for the study.

\section{Study site}

Seedlings were placed on a cement platform in the Screenhouse of the Department of Plant and Environmental Biology, University of Ghana at temperature of $33^{\circ} \mathrm{C}$ and $75 \%$ relative humidity.

\section{Experimental design}

The experiment was carried out in Randomized Complete Block Design (RCBD) with split plot arrangement. It consisted of 5 replicates each with seven treatment blocks namely control, $50 \mathrm{mM} \mathrm{NaCl}, 100 \mathrm{mM} \mathrm{NaCl}, 150 \mathrm{mM} \mathrm{NaCl}$, normal, moderate, severe, and severe watering and salt $(150 \mathrm{mM} \mathrm{NaCl})$ with each block having three different treatments (control, 100 $\mathrm{mM} \mathrm{SA}$ and $100 \mathrm{mM} \mathrm{KNO}_{3}$ ).

\section{Watering regime}

$100 \mathrm{ml}$ of water was used in watering each plant and all seedlings were saturated with water for the first four weeks under each treatment block. Three watering regimes were used in the study, namely, normal (rehydrated every other day), moderate (rehydrated every 3 days) and severe (rehydrated every 5 days).

\section{$\mathrm{NaCl}$ solution preparation.}

Commercially sold halite, commonly known as rock salt was used. Concentrations of $50 \mathrm{mM}$, $100 \mathrm{mM}$, and $150 \mathrm{mM}$ were prepared. These were applied to plants that were subjected to the different concentrations of $\mathrm{NaCl}$ using a measuring cylinder. 
Hormone application

$20 \mathrm{ml}$ of $50 \mu \mathrm{M}$ SA solution was applied to plants, subjected to this treatment, using a measuring cylinder. This was done once a week for seven weeks.

\section{Potassium nitrate application}

Twenty (20) $\mathrm{ml}$ of $50 \mu \mathrm{M} \mathrm{KNO}_{3}$ solution was applied to plant subjected to this treatment once a week.

\section{Data collection}

The height of each plant in all blocks was measured with a meter rule for seven (7) weeks. This was done by measuring from the surface of the soil to the terminal bud at the apex of the plant. Days to first anthesis were recorded for each test plant.

\section{Data analysis}

All data collected were statistically analysed using ANOVA from Minitab version 17 (Minitab, LLC).

\section{Results}

Effect of $\mathrm{SA}$ and $\mathrm{KNO}_{3}$ on mean plant height treated with varying concentrations of $\mathrm{NaCl}$ It was observed that, as $\mathrm{NaCl}$ concentration increased, there was a reduction in plant height (Table 1). However, plants treated with SA and $\mathrm{KNO}_{3}$ under different $\mathrm{NaCl}$ concentrations recorded marginally higher mean plant height values compared to their respective controls treated with only $\mathrm{NaCl}$ (Table 1) although the differences were not statistically significant $(\mathrm{F}$ $=2.73, \mathrm{P}=0.008$ ).

TABLE 1

Effect of $\mathrm{KNO}_{3}$ and $\mathrm{SA}$ on plant height under varying concentrations of $\mathrm{NaCl}$. Mean plant height \pm SE $(\mathrm{cm})$

\begin{tabular}{cccc}
$\begin{array}{c}\mathrm{NaCl} \text { Conc. } \\
(\mathrm{mM})\end{array}$ & Control $\pm \mathrm{SE}$ & $\mathrm{SA} \pm \mathrm{SE}$ & $\mathrm{KNO}_{3} \pm \mathrm{SE}$ \\
\hline 0 & $45.35 \pm 3.73 \mathrm{ab}$ & $46.34 \pm 3.74 \mathrm{ab}$ & $50.62 \pm 5.52 \mathrm{a}$ \\
50 & $41.55 \pm 1.45 \mathrm{ab}$ & $45.55 \pm 3.04 \mathrm{ab}$ & $47.87 \pm 6.62 \mathrm{ab}$ \\
100 & $40.98 \pm 3.31 \mathrm{ab}$ & $42.27 \pm 2.92 \mathrm{ab}$ & $47.29 \pm 2.4 \mathrm{ab}$ \\
150 & $39.18 \pm 6.62 \mathrm{~b}$ & $42.17 \pm 5.75 \mathrm{ab}$ & $42.88 \pm 3.14 \mathrm{ab}$ \\
\hline
\end{tabular}

Means that do not share a letter are significantly different.

Plants under $\mathrm{NaCl}$ stress treated with $\mathrm{KNO}_{3}$ showed higher plant height values compared to their respective controls (Table 1) and they were significantly different $(\mathrm{F}=5.58, \mathrm{P}=$ $0.000)$.
Effect of SA and $\mathrm{KNO}_{3}$ on mean plant height in plants treated with varying watering regimes at maturity

Plant height generally decreased as the water stress level increased, thus, plant height was inversely proportional to the increasing water stress. Plants treated with $\mathrm{KNO}_{3}$ recorded 
higher plant height compared to those treated with SA (Fig 1). Seedlings treated with SA recorded higher plant height values than the control plants (Fig. 1). The differences observed in plant height were statistically significant $(\mathrm{F}=6.74, \mathrm{P}=0.00)$.

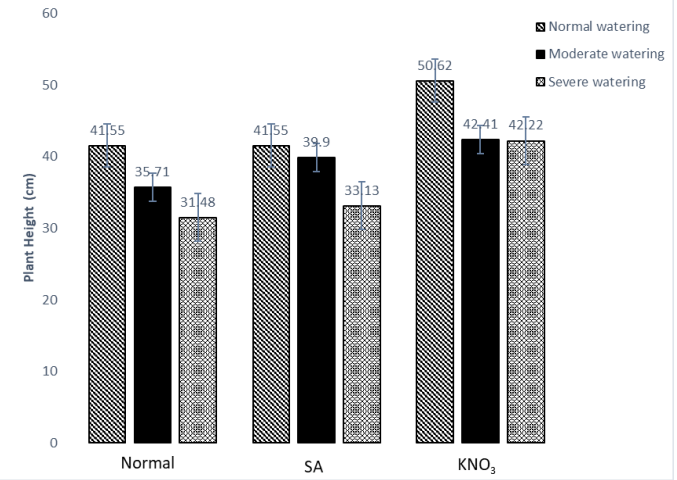

Fig. 1: Effect of SA and $\mathrm{KNO}_{3}$ on plant height under different water stress (control, moderate and severe).

When plants treated with $\mathrm{SA}$ and $\mathrm{KNO}_{3}$ under different watering regimes were compared, it was observed that plant height increased in both moderate and severe water stress levels (Fig. 2B \& Fig. 2C) whereas control plants without $\mathrm{SA}$ and $\mathrm{KNO}_{3}$ recorded reduced plant height (Fig. 2A).
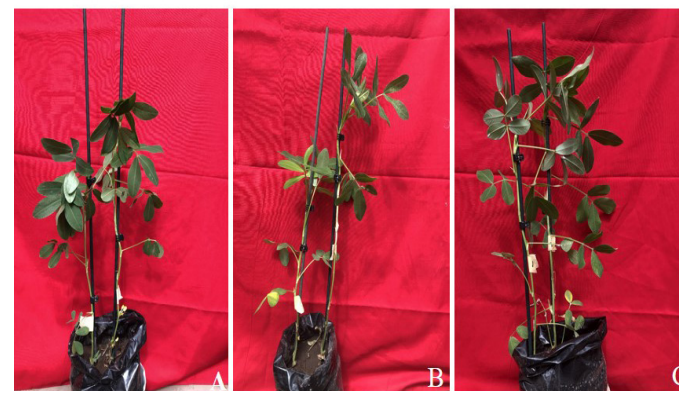

Fig. 2: Effect of $\mathrm{KNO}_{3}$ and $\mathrm{SA}$ on groundnut plant height under moderate watering 63 DAP. A. Control. B. Plants treated with SA. C. Plants treated with $\mathrm{KNO}_{3}$.
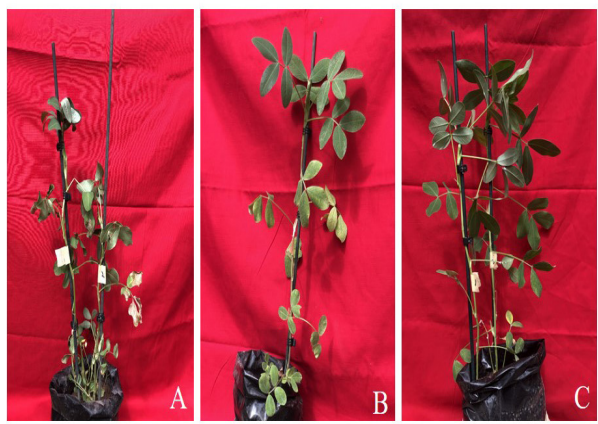

Fig. 3: Effect of SA and $\mathrm{KNO}_{3}$ on plant height under severe water stress combined with high salinity stress of $150 \mathrm{mM} \mathrm{NaCl}$ at 63 DAP. A. Control. B. Plants treated with SA. C. Plants treated with $\mathrm{KNO}_{3}$.

Combined high salinity concentration and severe water treatments

A comparison made between combined 150 $\mathrm{mM} \mathrm{NaCl}$ and severe water treatment at 63 DAP showed that mean plant height decreased significantly $(\mathrm{F}=13.50, \mathrm{P}=0.00)$ in plants that were exposed to simultaneous water and salinity stresses (Fig. 3A) in contrast with the plants treated with $\mathrm{KNO}_{3}$ and SA (Fig. 3B \& 3C). It was also observed that plants that were treated with $\mathrm{KNO}_{3}$ recorded higher plant heights followed by those that were treated with SA with control plants recording the lowest plant height of $33.8 \mathrm{~cm}$ (Fig. 4)

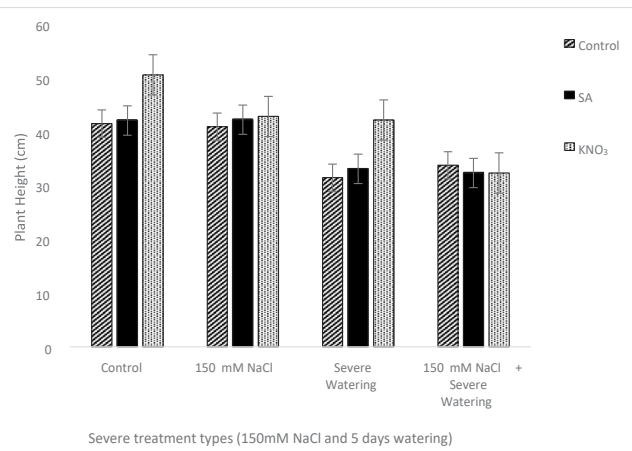

Fig. 4: Effect of $\mathrm{SA}$ and $\mathrm{KNO}_{3}$ on severe treatment types. 
Days to flowering (Anthesis)

First flowering was observed after 31 days. Plants that were not subjected to any stress flowered earlier compared to those that underwent stress (Table 2). It was also observed that plants under all treatment blocks treated with $\mathrm{KNO}_{3}$ flowered earlier (32 DAP) compared to plants treated with SA whilst the control plants had extended flowering time by 2 to 7 days. The number of days to flowering were significantly different $(\mathrm{F}=73.37, \mathrm{P}=$ $0.00)$.

TABLE 2

Days to flowering in groundnut plants under all indicated treatments.

\begin{tabular}{lcll} 
& Control $\pm \mathrm{SE}$ & $\mathrm{SA} \pm \mathrm{SE}$ & $\mathrm{KNO}_{3} \pm \mathrm{SE}$ \\
\hline Normal (control) & $34 \pm 0.9 \mathrm{ijk}$ & $33 \pm 1.1 \mathrm{k}$ & $32 \pm 1.1 \mathrm{k}$ \\
$50 \mathrm{mM} \mathrm{NaCl}$ & $40 \pm 2.41 \mathrm{efgh}$ & $38 \pm 2.9 \mathrm{ghi}$ & $35 \pm 1.140 \mathrm{ijk}$ \\
$100 \mathrm{mM} \mathrm{NaCl}$ & $42 \pm 2.41 \mathrm{ef}$ & $41 \pm 2.42 \mathrm{ef}$ & $40 \pm 1.8 \mathrm{fgh}$ \\
$150 \mathrm{mM} \mathrm{NaCl}$ & $44 \pm 1.8 \mathrm{def}$ & $42 \pm 1.1 \mathrm{ef}$ & $41 \pm 2.3 \mathrm{efg}$ \\
Moderate watering & $37 \pm 1.6 \mathrm{hij}$ & $34 \pm 1.1 \mathrm{jk}$ & $32 \pm 2.2 \mathrm{ef}$ \\
Severe watering & $47 \pm 1.6 \mathrm{~cd}$ & $44 \pm 1.3 \mathrm{de}$ & $43 \pm 1.5 \mathrm{k}$ \\
Severe watering and & $57 \pm 1.6 \mathrm{a}$ & $53 \pm 2.4 \mathrm{~b}$ & $51 \pm 2.2 \mathrm{bc}$ \\
$150 \mathrm{mM} \mathrm{NaCl}$ & &
\end{tabular}

Means that do not share a letter are significantly different.

\section{Discussion}

\section{Effect of $\mathrm{NaCl}$ stress on plant height}

Groundnut plants exposed to $\mathrm{NaCl}$ stress exhibited a decrease in height as salinity stress is known to cause stunted growth in plants (Isayenkov, 2019). In this paper, plants that underwent severe $\mathrm{NaCl}$ stress recorded the least plant height compared to the others. Our observations in this paper agree with the findings of Acosta-Motos et al. (2017), who reported that water used for cell division and growth is moved out of the plant as a result of an increase in $\mathrm{NaCl}$ concentration in the soil.

\section{Effect of SA and $\mathrm{KNO}_{3}$ on plant height under} $\mathrm{NaCl}$ stress

Both SA and $\mathrm{KNO}_{3}$ improved plant height as compared to their controls. SA was able to ameliorate the negative effects of $\mathrm{NaCl}$ stress because it has been shown to reduce the damaging effect of salinity on plant growth, accelerate the restoration of growth processes and reverse the effects of salinity (Fayez \& Bazaid, 2014). Potassium nitrate has been shown to be effective in mitigating the negative effects of salinity on coriander plants (Elhindi et al., 2016). This present study showed that $\mathrm{NaCl}$ stressed plants treated with $\mathrm{KNO}_{3}$ had higher plant heights. This agrees with work by Ahmad et al (2019) who reported that $\mathrm{KNO}_{3}$ increased plant growth by enhancing its physiological process as potassium $(\mathrm{K})$ plays a key role in stomatal conductance, photosynthesis osmoregulation, protein synthesis and turgor pressure-driven solute transport in the xylem to plant.

\section{Effect of water stress on plant height}

Drought is known to cause stunted growth in plants (Yadav et al., 2020). Plants under water stress in this paper recorded a decrease in height compared to their controls. This agrees with results by Vurayai et al. (2011), which showed that water stress at different stages of growth and development of Bambara groundnut plants significantly reduced plant height compared to non-stressed control plants. 
Effect of SA and $\mathrm{KNO}_{3}$ on plant height under water stress

Results from this paper demonstrates that salicylic acid improved or increased the height of plants exposed to water stress. These findings agree with results of Nakandala et al. ( 2016) who reported that the application of SA to plants generally had a positive effect on vegetative growth parameters such as plant height and leaf size. Furthermore, Fayez \& Bazaid (2014) also found that exogenous SA application was very effective in reducing the adverse effects of drought stress in sunflower. We also found that, higher plant height values were recorded in plants that were treated with $\mathrm{KNO}_{3}$ as compared to those that were not treated with $\mathrm{KNO}_{3}$ even though they were all undergoing drought stress. Wang et al. (2013) have reported that $\mathrm{KNO}_{3}$ is known to promote cell elongation during drought stress in plants. Combined effect of high salinity stress and severe water treatments on plant height

Drought and salinity stresses are known to have a profound negative effect on plants (Jaleel et al., 2009). Results from this present study showed that height of plants subjected to the combined effect of severe conditions of drought and saline stress recorded the least plant height values as observed by de Oliveira et al., (2016) who stated that drought and salinity stress are indeed known to reduce plant growth.

Effect of $\mathrm{SA}$ and $\mathrm{KNO}_{3}$ on plant height under combined drought and high salinity stress.

SA has been shown to improve plant growth during water and salinity stress (Faghih et al., 2019; Nazar et al., 2015) not excepting an increment in plant height. Results from our investigations showed that there was an increase in height of plants exposed simultaneously to severe water and $150 \mathrm{mM}$ $\mathrm{NaCl}$ when SA was applied. Studies from
Manzoor et al., ( 2015) showed that SA at a concentration of $0.5 \mathrm{mM}$ is more effective in contributing to the reduction of extreme saline impacts, significant increase germination rate and drought tolerance in maize seedlings. This study revealed that $\mathrm{KNO}_{3}$ aided in reversing the negative effect of both severe drought and $150 \mathrm{mM} \mathrm{NaCl}$ stress on plant height. Fayez \& Bazaid (2014) also showed that $\mathrm{KNO}_{3}$ reversed the negative effects of drought and salinity stress in barley.

\section{Effect of $\mathrm{NaCl}$ stress on flowering}

In this paper, we reported that $\mathrm{NaCl}$ stress affected flowering time. Thus, plants exposed to higher concentration of $\mathrm{NaCl}$ recorded a delay in flowering compared to those exposed to lower concentrations of $\mathrm{NaCl}$ (Table 2). This agrees with the report by Julien et al. (2019) who stated that increasing salinity delayed plant flowering in a local cultivar of chili pepper (Capsicum frutescens L.).

Effect of $\mathrm{SA}$ and $\mathrm{KNO}_{3}$ on flowering under $\mathrm{NaCl}$ stress

In our investigations, plants under $\mathrm{NaCl}$ stress treated with $\mathrm{SA}$ and $\mathrm{KNO}_{3}$ flowered earlier as compared to their respective controls. However, it was further seen that plants under all three $\mathrm{NaCl}$ concentrations treated with $\mathrm{KNO}_{3}$ flowered earlier than those treated with SA (Table 2). Flowering delayed as $\mathrm{NaCl}$ stress increased even though $\mathrm{KNO}_{3}$ and SA were applied. These findings agree with that of Attia (2016) who indicated that under salt stress conditions, the application of SA and $\mathrm{KNO}_{3}$ separately or combined accelerated flowering of olive trees.

Effect of water stress on flowering

Varying drought stress conditions may have different effects on flowering. Drought causes floral development to be arrested early and leads to sterility (Smith \& Zhao, 2016). 
Results from the paper of Kazan \& Lyons (2016) showed that in Arabidopsis, drought stress accelerated flowering under long days but delayed flowering under short days. On the contrary, plants under severe water conditions delayed the most in flowering compared to plants subjected to moderate and normal watering in this present study similar to flowering of Arabidopsis under short days.

\section{Effect of $\mathrm{SA}$ and $\mathrm{KNO}_{3}$ on flowering under water stress}

SA has been shown to reverse the effect of water stress on flowering (Hussain et al., 2008). In this study, it was observed that plants treated with SA under severe water stress conditions flowered earlier than their respective controls. However, flowering was delayed as stress level increased. Thus, plants under moderate watering regimes flowered earlier than those under severe watering regimes even though they were all treated with SA. These findings were similar to those of Rihan (2017) who showed that SA application enhanced the activities of different physiological and biochemical features, such as photosynthetic reactions, flowering, and plant growth which may also contribute to fruit yield and productivity in the wheat plant.

\section{Conclusion}

Plants treated with SA and $\mathrm{KNO}_{3}$ reversed reduction of plant height in salt and water stressed plants. Delayed anthesis was reversed by application $\mathrm{SA}$ and $\mathrm{KNO}_{3}$. However, ameliorating effect of $\mathrm{KNO}_{3}$ was more pronounced as compared with SA in water and salinity induced stress treatments.

\section{References}

Acosta-Motos, J. R., Ortuño, M. F., BernalVicente, A., Diaz-Vivancos, P., SanchezBlanco, M. J. \& Hernandez, J. A. (2017) Plant responses to salt stress: Adaptive mechanisms. Agronomy 7 (1), https://doi. org/10.3390/agronomy7010018.

Ahmad, W., Ayyub, C. M., Shehzad, M. A., Ziaf, K., IJAZ, M., Sher, A., Abbas, T. \& Shafi, J. (2019) Supplemental potassium mediates antioxidant metabolism , physiological processes and osmoregulation to confer salt stress tolerance in cabbage (Brassica oleracea L.). Horticulture, Environment, and Biotechnology 60, 853 - 869. https://doi.org/10.1007/s13580019-00172-2.

Asravor, J. Wiredu, A. N., Siddig, K. \& Onumah, E. E. (2019) Evaluating the EnvironmentalTechnology Gaps of Rice Farms in Distinct Agro-Ecological Zones of Ghana. Sustainability 11 (7), 2072.

AtтiA, M. F. (2016) Foliar spray with potassium nitrate and salicylic acid for improving growth , yield and nutrients uptake by olive trees under salinity stress conditions. International Journal of Chem Tech Research. 9 (12), 230 -244 .

Baher, Z. F., Mirza, M., Ghorbanli, M. \& RezaiI, M. B. (2002) The influence of water stress on plant height, herbal and essential oil yield and composition in Satureja hortensis L. Flavour Fragr. J. 17, $275-277$.

Basu, S., Ramegowda, V., Kumar, A. \& Pereira, A. (2016) Plant adaptation to drought stress. F1000Research 1554 - 1554. https://doi. org/10.12688/f1000research.7678.1.

Bodner, G., NAKhforoosh, A. \& KaUl, H. P. (2015) Management of crop water under drought: a review. Agron. Sustain. Dev. 35, $401-442$. https://doi.org/10.1007/s13593-015-0283-4. 
Dempsey, D. A. \& Klessig, D. F. (2017) How does the multifaceted plant hormone salicylic acid combat disease in plants and are similar mechanisms utilized in humans?. BMC Biol 15, 23 . https://doi.org/10.1186/s12915-0170364-8.

De Oliveira, A. B., Alencar, N. L. M. \& GomesFILHo, E. (2016) Comparison between the Water and Salt Stress Effects on Plant Growth and Development. November. Intech. 68-94 https://doi.org/10.5772/54223.

El-Katony T. M., El-Bastawisy Z. M., El-Ghareeb S. S. (2019) Timing of salicylic acid application affects the response of maize (Zea mays L.) hybrids to salinity stress. Heliyon 5 (4), e01547. doi: 10.1016/j.heliyon.2019.e01547. PMID: 31183422; PMCID: PMC6488542.

Elhindi, K. M., El-Hendawy, S., Abdel-Salam, E., Schmidhalter, U., Rehman, S. U., \& Hassan, A. A. (2016) Foliar application of potassium nitrate affects the growth and photosynthesis in coriander (Coriander sativum L.) plants under salinity. Progress in Nutrition 18 (1), 63 - 7. https://www.mattioli1885journals.com/index. php/progressinnutrition/article/view/4359.

Faghin, S., Zarei, A. \& Ghobadi, C. (2019) Positive effects of plant growth regulators on physiology responses of Fragaria $x$ ananassa cv . 'Camarosa' under salt stress. International Journal of Fruit Science 19 (1), 104 - 114. https://doi.org/10.1080/15538362.2 018.1462291 .

Fahad, S., Bajwa, A. A., Nazir, U., Anjum, S. A., \& FarooQ, A. (2017). Crop Production under Drought and Heat Stress : Plant Responses and Management Options 8, 1 - 16. https://doi. org/10.3389/fpls.2017.01147.

Falster, D. S. \& Westoby, M. (2003) Plant height and evolutionary games. Trends in Ecology and Evolution 18 (7), 337 - 343.

FAYEZ, K. A. \& BAZAID, S. A. (2014) Improving drought and salinity tolerance in barley by application of salicylic acid and potassium nitrate. Journal of the Saudi Society of Agricultural Sciences
13 (1), 45 - 55 https://doi.org/10.1016/j. jssas.2013.01.001.

Gupta, B. \& Huang, B. (2014) Mechanism of salinity tolerance in plants: Physiological, biochemical, and molecular characterization. In International Journal of Genomics 2014, 1 - 19. https://doi.org/10.1155/2014/701596.

GuptA, S. K. (2012) Technological innovations in major world oil crops. Breeding (1st ed.). New York, NY: Springer New York : Imprint: Springer., https://doi.org/10.1007/978-1-46140356-2.

Hanumantharao, B. Nair, R. M. \& Nayyar, H. (2016) Salinity and high temperature tolerance in mungbean [Vigna radiata (L.) Wilczek] from a physiological perspective. Frontiers in Plant Science 7, 957 https://doi.org/10.3389/ fpls.2016.00957.

Hasanuzzaman, M., Nahar, K., Bhuiyan, T. F., Anee, T. I., Inafuku, M., OKu, H., \& Fujita, M. (2017) Salicylic Acid: An All-Rounder in Regulating Abiotic Stress Responses in Plants. Phytohormones - Signaling Mechanisms and Crosstalk in Plant Development and Stress Responses. https://doi.org/10.5772/ intechopen.68213

Hussain, M., Malik, M. A., Faroog, M., Ashraf, M. Y. \& CheEmA, M. A. (2008) Improving Drought Tolerance by Exogenous Application of Glycinebetaine and Salicylic Acid in Sunflower. Journal of Agronomy and Crop Science 194 (3), 193 - 199. https://doi. org/10.1111/j.1439-037X.2008.00305.x.

Isayenkov, S. V. (2019) Plant Salinity Stress : Many Unanswered Questions Remain. Frontiers in Plant Science 10, 1 - 80. https://doi. org/10.3389/fpls.2019.00080

Jaleel, C. A., Manivannan, P., Wahid, A., FarooQ, M., Al-Juburi, H. J., Somasundaram, R. \& Panneerselvam, R. (2009) Drought stress in plants: A review on morphological characteristics and pigments composition. International Journal of Agriculture and Biology 11, 100 - 105. 
Jung, S., Tate, P. L., Horn, R., Kochert, G., Moore, K. \& Abbott, A. G. (2003) The phylogenetic relationship of possible progenitors of the cultivated peanut. Journal of Heredity 94 (4), 334 - 340. https://doi.org/10.1093/jhered/ esg061.

KazAn, K. \& Lyons, R. (2016) The link between flowering time and stress tolerance. Journal of Experimental Botany 67 (1), 47 - 60. https:// doi.org/10.1093/jxb/erv441.

Khan, M. I. R., Fatma, M., Per, T. S., Anjum, N. A. \& Khan, N. A. (2015) Salicylic acid-induced abiotic stress tolerance and underlying mechanisms in plants. Frontiers in Plant Science. 6, 462 https://doi.org/10.3389/ fpls.2015.00462.

Klessig, D. F. \& Malamy, J. (1994) The salicylic acid signal in plants. Plant Molecular Biology 26 (5), $1439-1458$.

Koffi, K., N'dri, A., Lata, J., Konaté, S., Srikanthasamy, T., Konan, M. \& Barot, S. (2019) Effect of fire regime on the grass community of the humid savanna of Lamto, Ivory Coast. Journal of Tropical Ecology $\mathbf{3 5}$ (1), 1-7. doi:10.1017/S0266467418000391.

Kpinkoun, J. K., Amoussa, A. M., Mensah, A. C. G., Komlan, F. A., Kinsou, E., Lagnika, L. \& Gandonou, C. B. (2019) Effect of salt stress on flowering, fructification and fruit nutrients concentration in a local cultivar of chili pepper (Capsicum frutescens L.). International Journal of Plant Physiology and Biochemistry $11(1), 1-7$

Lamalakshmi Devi, E., Kumar, S., Basanta Singh, T., Sharma, S. K., Beemrote, A., Devi, C. P., Chongtham, S. K., Singh, C. H., Yumlembam, R. A., Haribhushan, A., Prakash, N. \& Wani, S. H. (2017) Adaptation strategies and defence mechanisms of plants during environmental stress. In Medicinal Plants and Environmental Challenges, 359 - 413. https://doi.org/10.1007/978-3-31968717-9 20
Liang, M., XiaO, S., Cai, J. \& Ow, D. W. (2019) Oxidative stress regulates drought-induced flowering through APETALA 1, Biochemical and Biophysical Research Communications 519 (3), 585 - 590, ISSN 0006-291X, https:// doi.org/10.1016/j.bbrc.2019.08.154.

LiU, X., Wang, X., Wang X, Gao, J., Luo, N., Meng, Q. \& Wang, P (2020). Dissecting the critical stage in the response of maize kernel set to individual and combined drought and heat stress around flowering. Environmental and Experimental Botany 179, 104213, ISSN 0098-8472, https://doi.org/10.1016/j. envexpbot.2020.104213.

Manzoor, K., Ilyas, N., Batool, N., Ahmad, B. \& Arshad, M. (2015) Effect of salicylic acid on the growth and physiological characteristics of maize under stress conditions. Journal of the Chemical Society of Pakistan 37 (3), 588 - 593.

Nagashima, H. \& Hikosaka, K. (2011) Plants in a crowded stand regulate their height growth so as to maintain similar heights to neighbours even when they have potential advantages in height growth. Annals of Botany 108, 207 214.

Nakandala, S. A., Weerasinghe, K. D. N., Senevirathne, P., Iqbal, S. M. M., Lakmini, W. G. D. \& ViJithasiRi, P. M. P. S. (2016) Exogenous application of Salicylic Acid alleviates drought stress of rubber nursery plants in the Intermediate Zone of Sri Lanka. Journal of the Rubber Research Institute of Sri Lanka 96, 50 - 58. DOI: http://doi.org/10.4038/ jrrisl.v96i0.1841.

NAZAR, R., Umar, S., Khan, N. A. \& SAREer, O. (2015) Salicylic acid supplementation improves photosynthesis and growth in mustard through changes in proline accumulation and ethylene formation under drought stress. South African Journal of Botany 98, 84 - 94. https://doi. org/10.1016/j.sajb.2015.02.005

Niklas, K. J. (2002) Maximum plant height and the biophysical factors that limit it. Tree Physiology 27, $433-440$. 
Olson, M. E., Soriano, D., Rosell, J. A., Anfodillo, T., Donoghue, M.J., Edwards, E. J., León-Gómez, C., Dawson, T., Camarero Martínez, J. J., Castorena, M., Echeverría, A., Espinosa, C.I., Fajardo, A., Gazol, A., Isnard S., Lima, R. S., Marcatil, C. R. \& MÉNDEZ-Alonzo, R. (2018) Plant height and hydraulic vulnerability to drought and cold. PNAS 115 (29), 7551 - 7556.

Pitman M. G. \& LÄUchli, A. (2002) Global Impact of Salinity and Agricultural Ecosystems. In: Läuchli A., Lüttge U. (eds) Salinity: Environment - Plants - Molecules. Springer, 3 - 20. Dordrecht. https://doi.org/10.1007/0-30648155-3_1.

Pradheeban, L., Nissanka, S. P. \& Suriyagoda, L. D. B. (2017) Influence of whole and sub soil salinity on growth, development, physiology and yield of selected rice varieties cultivated in Jaffna district, Sri Lanka. Tropical Agricultural Research 28 (4), 389 - 401. https://doi. org/10.4038/tar.v28i4.8240.

Rihan, H. (2017) The Effect of Exogenous Applications of Salicylic Acid and Molybdenum on the Tolerance of Drought in Wheat. Agricultural Research \& Technology: Open Access Journal 9 (4), 97 - 105. https://doi.org/10.19080/ artoaj.2017.09.555768

SaAdatmand, A. R., Banihashemi, Z., Maftoun, M. \& Sepaskhah, A. R. (2007) Interactive Effect of Soil Salinity and Water Stress on Growth and Chemical Compositions of Pistachio Nut Tree. Journal of Plant Nutrition 30 (12), 2037 -2050 .

ShiYAm, J. (2010) Growthand yield response of groundnut (Arachis hypogaea 1.) to plant densities and phosphorus on an ultisol in southeastern Nigeria. Nigeria Agricultural Journal 40 (1), 161 - 165. https://doi. org/10.4314/naj.v40i1-2.55549.

Smith, A. R. \& Zhao, D. (2016) Sterility Caused by Floral Organ Degeneration and Abiotic Stresses in Arabidopsis and Cereal Grains.
Frontiers in Plant Science 7, 1 - 15. https:// doi.org/10.3389/fpls.2016.01503.

Su, Z., Ma X., Guo H., Sukiran, N. L., Guo, B., Assmann, S. M. \& Ma, H. (2013) Flower development under drought stress: morphological and transcriptome analyses reveal acute responses and long-term acclimation in Arabidopsis. The Plant Cell 25, $3785-3807$.

Vurayai, R., Emongor, V., Moseki, B. \& R. Vurayai, V. EMONGOR, B. M. (2012) Physiological Responses of Bambara Groundnut (Vigna subterranea L. Verdc) to Short Periods of Water Stress During Different Developmental Stages. Asian Journal of Agricultural Sciences 3 (1).

Waitz, Y., Wasserstrom, H., Hanin, N., Landau, N., Faraj, T., Barzilai, M., ZifFer-Berger, J. \& Barazani, O. (2021) Close association between flowering time and aridity gradient for Sarcopoterium spinosum in Israel, Journal of Arid Environments 188. 104468, ISSN 0140-1963.

Wang, M., Zheng, Q., Shen, Q. \& Guo, S. (2013) The critical role of potassium in plant stress response. International Journal of Molecular Sciences 14 (4), 7370 -7390. https://doi. org/10.3390/ijms 14047370 .

Yadav, T., Kumar, A., Yadav, R. K., YadaV, G., Kumar, R. \& Kushwaha, M. (2020) Salicylic acid and thiourea mitigate the salinity and drought stress on physiological traits governing yield in pearl millet-wheat. Saudi Journal of Biological Sciences 27, 2010 - 2017.

Zunzunegui, M., Sánchez, J. A. M., Barradas, M. C. D. \& Gallego-Fernández, J. B. (2021) Different tolerance to salinity of two populations of Oenothera drummondii with contrasted biogeographical origin. Plant Physiology and Biochemistry 162, 336 - 348. ISSN 0981-9428, https://doi.org/10.1016/j. plaphy.2021.03.001. 